\title{
The Safety Profile of Upadacitinib in Patients with Rheumatoid Arthritis in Japan
}

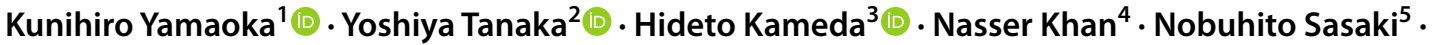

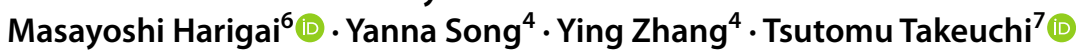

Accepted: 30 March 2021 / Published online: 27 May 2021

(c) The Author(s) 2021

\begin{abstract}
Introduction Upadacitinib is a Janus kinase inhibitor with demonstrated efficacy in patients with rheumatoid arthritis (RA). Objective The aim of this study was to assess the long-term safety of upadacitinib in patients with active RA from Japan compared with global clinical trial populations.

Methods Pooled data in patients enrolled from Japan (the 'Japanese population'; SELECT-SUNRISE, SELECT-EARLY, and SELECT-MONOTHERAPY) were compared with that from global (Japan and ex-Japan) upadacitinib clinical trial populations and summarized descriptively.

Results The Japanese population (mean age 57.0 years; mean RA duration 6.1 years) received upadacitinib $7.5 \mathrm{mg}(n=121)$, $15 \mathrm{mg}(n=126)$, and $30 \mathrm{mg}(n=124)$ once daily, while the global population (mean age 54.8 years; mean RA duration 9.1 years) received upadacitinib $6 \mathrm{mg}$ twice daily/15 mg once daily $(n=2883)$ and $12 \mathrm{mg}$ twice daily/30 $\mathrm{mg}$ once daily $(n=1375)$. Most patients were female (79.3\%). The exposure-adjusted incidence rates (EAIRs) of serious adverse events in the Japanese population were 11.5, 12.2, and 21.2 per 100 patient-years (PY) with upadacitinib 7.5, 15, and $30 \mathrm{mg}$, respectively. Herpes zoster rates were higher in the Japanese population $(7.8,12.4$, and 16.7 per $100 \mathrm{PY}$ with $7.5,15$, and $30 \mathrm{mg}$, respectively) versus global populations ( 3.7 and 7.0 per $100 \mathrm{PY}$ with 15 and $30 \mathrm{mg}$, respectively). Prior herpes zoster was a significant risk factor for herpes zoster.

Conclusions The safety profile of upadacitinib was generally similar between Japanese and global RA populations, except for higher EAIRs for serious adverse events and infections, including herpes zoster, in the Japanese population.

Trial Registration Numbers SELECT-EARLY: NCT02706873; SELECT-NEXT: NCT02675426; SELECT-COMPARE: NCT02629159; SELECT-MONOTHERAPY: NCT02706951; SELECT-BEYOND: NCT02706847; SELECT-SUNRISE: NCT02720523; BALANCE I: NCT01960855; BALANCE II: NCT02066389.
\end{abstract}

Kunihiro Yamaoka

yamaokak@gmail.com

1 Department of Rheumatology and Infectious Diseases, Kitasato University School of Medicine, Kanagawa, Japan

2 The First Department of Internal Medicine, University of Occupational and Environmental Health, Kitakyushu, Japan

3 Department of Internal Medicine, Division of Rheumatology, Toho University (Ohashi Medical Center), Tokyo, Japan

4 AbbVie Inc., North Chicago, IL, USA

5 Immunology, AbbVie GK, Tokyo, Japan

6 Department of Rheumatology, Tokyo Women's Medical University School of Medicine, Tokyo, Japan

7 Department of Internal Medicine, Division of Rheumatology, Keio University School of Medicine, Tokyo, Japan

\section{Introduction}

The Janus kinase (JAK) family are important mediators of types I and II cytokine receptor signaling pathways involved in normal cellular processes as well as in the pathogenesis of rheumatoid arthritis (RA) and other immune-mediated inflammatory diseases [1-3]. Upadacitinib (ABT-494) is an oral JAK inhibitor engineered for greater selectivity for JAK1 versus JAK2, JAK3, and TYK2 based on in vitro analysis [4]. Upadacitinib has demonstrated clinical and functional efficacy in diverse RA populations, both in combination with conventional synthetic disease-modifying antirheumatic drugs (csDMARDs) and as monotherapy [5-10]. Adverse events of special interest (AESIs) with upadacitinib include serious infections, opportunistic infections, herpes 


\section{Key Points}

Upadacitinib is an oral Janus kinase inhibitor that has been approved for the treatment of rheumatoid arthritis (RA) at a dose of $15 \mathrm{mg}$ once daily in the European Union and United States, and at doses of 7.5 and $15 \mathrm{mg}$ once daily in Japan.

Compared with the global RA clinical trial population, a higher incidence of serious infections, opportunistic infections, herpes zoster, and creatine phosphokinase elevations was observed in the Japanese population; this increased risk of herpes zoster should be considered when assessing the benefit-risk of prescribing upadacitinib.

In the Japanese population, the safety profiles of upadacitinib $15 \mathrm{mg}$ and $7.5 \mathrm{mg}$ doses were generally similar, except for numerically lower rates of opportunistic infections, herpes zoster, and creatine phosphokinase elevations with the $7.5 \mathrm{mg}$ dose compared with the $15 \mathrm{mg}$ dose, although no statistical comparisons were conducted.

zoster, malignancies, major adverse cardiovascular events (MACE), and venous thromboembolism (VTE).

Differences may exist in the safety profiles of JAK inhibitors in patients from Asia compared with global patients with RA [11-15]. For example, a higher rate of infections, particularly herpes zoster, has previously been observed in patients treated with JAK inhibitors enrolled from clinical sites in Asia than patients enrolled from other regions [14, 15]. It is therefore necessary to determine the long-term safety profile of upadacitinib in Asia to identify any regionspecific safety signals. The purpose of this analysis was to assess the long-term safety of upadacitinib in patients with RA enrolled from Japan and compare this with the global (both Japan and ex-Japan) RA clinical trial population.

\section{Methods}

\subsection{Studies and Patients}

The Japanese population was defined as patients with RA who were enrolled in Japan from three ongoing, multicenter, randomized, double-blind trials of upadacitinib: two methotrexate-controlled phase III studies that included subsets of patients from Japan (SELECT-EARLY [9] and SELECTMONOTHERAPY [8]) and one placebo-controlled phase IIb/III study conducted exclusively in Japan (SELECTSUNRISE [16]). The safety of upadacitinib in these trials was compared with the global population (including patients from Japan and outside Japan), which included six phase III trials (SELECT-EARLY [9], SELECT-MONOTHERAPY [8], SELECT-SUNRISE [16], SELECT-NEXT [5], SELECT-BEYOND [7], and SELECT-COMPARE [6]) and two phase II dose-ranging studies (BALANCE I [17] and BALANCE II [18]). Details of all the trials included in this analysis have been published previously and are summarized in Table 1. Patients who completed the randomized, controlled periods of each study had the option to enter a long-term extension study, in which all patients received blinded or open-label treatment with upadacitinib.

All studies were conducted according to the International Conference on Harmonization of Technical Requirements for Pharmaceuticals for Human Use guidelines, applicable regulations and guidelines governing clinical study conduct, and the Declaration of Helsinki. Study-related documents were reviewed and approved by independent Ethics Committees and Institutional Review Boards. All patients provided written informed consent.

\subsection{Analysis}

Exposure-adjusted incidence rates (EAIRs) of adverse events (AEs) and AESIs per 100 patient-years (PY) were assessed. All AEs were treatment-emergent, defined as an onset date on or after the first dose of upadacitinib and up to 30 days after the last dose of upadacitinib. In patients who switched from upadacitinib to adalimumab in SELECTCOMPARE [6], AEs were censored at the switch date. The severity of AEs was evaluated using the Outcome Measures in Rheumatoid Arthritis Clinical Trials (OMERACT) Common Toxicity Criteria v2.0.

There was no statistical testing between treatment groups or between the Japanese and global populations, therefore all comparisons were summarized descriptively. In the global population, twice-daily dosing of upadacitinib 6 and $12 \mathrm{mg}$ in phase II studies was considered nearly equivalent to the once-daily dosing of upadacitinib 15 and $30 \mathrm{mg}$ in phase III studies, respectively, based on pharmacokinetic analyses [19].

Univariable Cox proportional hazards regression models were used to evaluate risk factors for serious infections and herpes zoster in the Japanese and global RA populations. Time to first infection was used as a response variable, with covariates as fixed factors. Multivariable Cox proportional hazards regression models with stepwise selection were used to evaluate risk factors for serious infections and herpes zoster. Hazard ratios with $95 \%$ confidence intervals (CIs) were reported. 
Table 1 Overview of the upadacitinib RA clinical development program

\begin{tabular}{|c|c|c|c|c|c|c|c|c|}
\hline Study & $\begin{array}{l}\text { BALANCE I } \\
{[17]}\end{array}$ & $\begin{array}{l}\text { BALANCE II } \\
{[18]}\end{array}$ & $\begin{array}{l}\text { SELECT- } \\
\text { SUNRISE }^{\text {a }} \\
{[16]}\end{array}$ & $\begin{array}{l}\text { SELECT- } \\
\text { EARLY }^{\mathrm{b}} \\
{[9]}\end{array}$ & $\begin{array}{l}\text { SELECT- } \\
\text { NEXT } \\
{[5]}\end{array}$ & $\begin{array}{l}\text { SELECT- } \\
\text { MONO- } \\
\text { THERAPYb } \\
{[8]}\end{array}$ & $\begin{array}{l}\text { SELECT- } \\
\text { COMPARE } \\
{[6]}\end{array}$ & $\begin{array}{l}\text { SELECT- } \\
\text { BEYOND } \\
{[7]}\end{array}$ \\
\hline Phase & $\mathrm{IIb}$ & $\mathrm{IIb}$ & $\mathrm{IIb} / \mathrm{III}$ & III & III & III & III & III \\
\hline Populations & TNFi-IR/Int & MTX-IR & $\begin{array}{l}\text { csDMARD- } \\
\text { IR }\end{array}$ & MTX-naïve & $\begin{array}{l}\text { csDMARD- } \\
\text { IR }\end{array}$ & MTX-IR & MTX-IR & bDMARD-IR \\
\hline $\begin{array}{l}\text { Number of } \\
\text { patients } \\
\text { randomized }\end{array}$ & 276 & 300 & 197 & $947^{\mathrm{b}}$ & 661 & $648^{\mathrm{b}}$ & 1629 & 498 \\
\hline $\begin{array}{l}\text { Background } \\
\text { therapy }\end{array}$ & MTX & MTX & csDMARDs & - & csDMARDs & - & MTX & csDMARDs \\
\hline $\begin{array}{l}\text { Upadacitinib } \\
\text { dose }\end{array}$ & $\begin{array}{l}3 \mathrm{mg} \text { twice } \\
\text { daily }^{\mathrm{c}} \\
6 \mathrm{mg} \text { twice } \\
\text { daily } \\
12 \mathrm{mg} \text { twice } \\
\text { daily } \\
18 \mathrm{mg} \text { twice } \\
\text { daily }^{\mathrm{c}}\end{array}$ & $\begin{array}{l}3 \mathrm{mg} \text { twice } \\
\text { daily }^{\mathrm{c}} \\
6 \mathrm{mg} \text { twice } \\
\text { daily } \\
12 \mathrm{mg} \text { twice } \\
\text { daily } \\
18 \mathrm{mg} \text { twice } \\
\text { daily }^{\mathrm{c}} \\
24 \mathrm{mg}^{\mathrm{m}} \text { once } \\
\text { daily }^{\mathrm{c}}\end{array}$ & $\begin{array}{l}7.5 \mathrm{mg} \text { once } \\
\text { daily } \\
15 \mathrm{mg} \text { once } \\
\text { daily } \\
30 \mathrm{mg} \text { once } \\
\text { daily }\end{array}$ & $\begin{array}{l}7.5 \mathrm{mg} \text { once } \\
\text { daily }^{\mathrm{a}} \\
15 \mathrm{mg} \text { once } \\
\text { daily } \\
30 \mathrm{mg} \text { once } \\
\text { daily }\end{array}$ & $\begin{array}{l}15 \mathrm{mg} \text { once } \\
\text { daily } \\
30 \mathrm{mg} \text { once } \\
\text { daily }\end{array}$ & $\begin{array}{l}15 \mathrm{mg} \text { once } \\
\text { daily } \\
30 \mathrm{mg} \text { once } \\
\text { daily }\end{array}$ & $\begin{array}{l}15 \mathrm{mg} \text { once } \\
\text { daily }\end{array}$ & $\begin{array}{l}15 \mathrm{mg} \text { once } \\
\text { daily } \\
30 \mathrm{mg} \text { once } \\
\text { daily }\end{array}$ \\
\hline Comparator & Placebo & Placebo & Placebo & MTX & Placebo & MTX & $\begin{array}{l}\text { Placebo } \\
\text { Adalimumab }\end{array}$ & Placebo \\
\hline
\end{tabular}

DDMARD biologic disease-modifying antirheumatic drug, $c S D M A R D$ conventional synthetic disease-modifying antirheumatic drug, Int intolerance, $I R$ inadequate response/responders, $M T X$ methotrexate, $R A$ rheumatoid arthritis, TNFi tumor necrosis factor inhibitor

a Japan only

${ }^{\mathrm{b}}$ SELECT-EARLY and SELECT-MONOTHERAPY included 138 and 61 patients, respectively, from Japan

${ }^{c}$ Patients receiving these doses were not included in the pooled RA global population for this integrated safety analysis

\section{Results}

\subsection{Patients}

Across the three trials, a total of 371 patients with RA were enrolled from Japan and received upadacitinib $7.5 \mathrm{mg}$ once daily $(n=121), 15 \mathrm{mg}$ once daily $(n=126)$, or $30 \mathrm{mg}$ once daily $(n=124)$. Median duration of exposure in the Japanese population was 604,611 , and 585 days in the $7.5,15$, and $30 \mathrm{mg}$ groups, respectively. In the global RA population, a total of 2883 patients received upadacitinib $6 \mathrm{mg}$ twice daily/15 mg once daily and 1375 patients received upadacitinib $12 \mathrm{mg}$ twice daily/30 $\mathrm{mg}$ once daily. For this population, median duration of exposure was 491 days in the $6 \mathrm{mg}$ twice daily/15 mg once daily group and 505 days in the 12 $\mathrm{mg}$ twice daily/30 $\mathrm{mg}$ once daily group.

Baseline demographics were generally well-balanced across treatment groups for both the Japanese and global RA populations (Table 2). Similar to the global population, most patients from the Japanese population were female and aged between 40 and 64 years. Compared with the global population, the Japanese population had a shorter RA duration but had similar levels of disease activity (which was measured using Disease Activity Score in 28 joints based on $\mathrm{C}$-reactive protein). Fewer patients in the Japanese population were receiving any csDMARDs at baseline compared with the global $6 \mathrm{mg}$ twice daily/15 mg once daily group. Methotrexate use was less frequent and at a lower mean dose (approved dose in Japan: 6-16 mg/week [20]) in the Japanese versus global populations, and patients in the Japanese population were also receiving lower doses of oral glucocorticoids at baseline. Weight and body mass index (BMI) were lower in patients in the Japanese population compared with the global population, whereas use of statins, elevated highdensity lipoprotein cholesterol, and low-density lipoprotein cholesterol were more common in the global population. A history of herpes zoster was more common in the Japanese population compared with the global population, while prior herpes zoster vaccination was less common.

\subsection{Overall Safety}

The EAIRs of AEs, AEs leading to discontinuation of study drug, and serious AEs in the Japanese population were higher in patients receiving upadacitinib $30 \mathrm{mg}$ compared with the 7.5 and $15 \mathrm{mg}$ doses (Table 3). EAIRs for these 
Table 2 Baseline characteristics in the upadacitinib Japanese and global RA populations

\begin{tabular}{|c|c|c|c|c|c|}
\hline \multirow[t]{2}{*}{ Characteristic } & \multicolumn{3}{|c|}{ Japanese RA population } & \multicolumn{2}{|c|}{ Global RA population } \\
\hline & $\begin{array}{l}\text { Upadacitinib } \\
7.5 \text { mg once daily } \\
{[n=121]}\end{array}$ & $\begin{array}{l}\text { Upadacitinib } \\
15 \text { mg once daily } \\
{[n=126]}\end{array}$ & $\begin{array}{l}\text { Upadacitinib } \\
30 \mathrm{mg} \text { once daily } \\
{[n=124]}\end{array}$ & $\begin{array}{l}\text { Upadacitinib } \\
6 \mathrm{mg} \text { twice daily/ } \\
15 \mathrm{mg} \text { once daily } \\
{[n=2883]}\end{array}$ & $\begin{array}{l}\text { Upadacitinib } \\
12 \mathrm{mg} \text { twice daily/ } \\
30 \mathrm{mg} \text { once daily } \\
{[n=1375]}\end{array}$ \\
\hline Female $[n(\%)]$ & $84(69.4)$ & $92(73.0)$ & $96(77.4)$ & $2296(79.6)$ & $1090(79.3)$ \\
\hline Race, Asian $[n(\%)]$ & $121(100.0)$ & $126(100.0)$ & $124(100.0)$ & $245(8.5)$ & $169(12.3)$ \\
\hline Age, years [mean (SD)] & $57.2(13.1)$ & $56.7(11.8)$ & $57.1(11.6)$ & $54.2(12.1)$ & $55.5(11.9)$ \\
\hline Weight, kg [mean (SD)] & $57.3(11.5)$ & $58.4(9.9)$ & $56.6(12.1)$ & $77.1(19.6)$ & $77.4(20.7)$ \\
\hline BMI, $\mathrm{kg} / \mathrm{m}^{2}$ [mean (SD)] & $22.5(3.4)$ & $23.1(3.6)$ & $22.8(4.5)$ & $28.9(6.7)^{\mathrm{a}}$ & $28.9(6.9)^{\mathrm{b}}$ \\
\hline \multicolumn{6}{|l|}{ Duration of RA since diagnosis, years } \\
\hline Mean (SD) & $6.0(7.9)$ & $6.7(9.0)$ & $5.5(6.1)$ & $9.4(8.6)^{\mathrm{c}}$ & $8.9(8.9)^{\mathrm{d}}$ \\
\hline Median (range) & $2.5(0.2-38.8)$ & $3.0(0.2-54.2)$ & $2.8(0.3-25.5)$ & $6.8(0.2-60.1)^{\mathrm{c}}$ & $5.7(0.1-51.7)^{\mathrm{d}}$ \\
\hline DAS28-CRP at baseline [mean (SD)] & $5.3(0.9)$ & $5.2(1.0)$ & $5.2(1.0)$ & $5.8(1.0)^{\mathrm{e}}$ & $5.7(1.0)^{\mathrm{b}}$ \\
\hline \multicolumn{6}{|l|}{$\begin{array}{l}\text { Concomitant csDMARDs at baseline } \\
{[n(\%)]}\end{array}$} \\
\hline None & $56(46.7)$ & $62(49.6)$ & $58(46.8)$ & $831(28.8)$ & $742(54.0)$ \\
\hline MTX alone & $34(28.3)$ & $36(28.8)$ & $46(37.1)$ & $1814(62.9)$ & $430(31.3)$ \\
\hline MTX + other csDMARDs & $17(14.2)$ & $15(12.0)$ & $12(9.7)$ & $118(4.1)$ & $93(6.8)$ \\
\hline csDMARDs other than MTX & $13(10.8)$ & $12(9.6)$ & $8(6.5)$ & $119(4.1)$ & $110(8.0)$ \\
\hline Missing & $1(0.8)$ & $1(0.8)$ & 0 & $1(<0.1)$ & 0 \\
\hline MTX dose at baseline ${ }^{\mathrm{f}}[$ mean (SD)] & $9.8(3.0)$ & $8.7(2.5)$ & $9.8(3.1)$ & $16.7(4.3)$ & $16.3(4.8)$ \\
\hline GCs at baseline ${ }^{\mathrm{g}}[n(\%)]$ & $59(48.8)$ & $70(55.6)$ & $57(46.0)$ & $1576(54.7)$ & $655(47.6)$ \\
\hline Oral GC dose at baseline ${ }^{\mathrm{h}}[$ mean (SD)] & $3.5(1.5)$ & $3.7(1.9)$ & $3.7(1.9)$ & $6.1(2.5)$ & $6.2(3.5)$ \\
\hline History of herpes zoster $[n(\%)]$ & $21(17.4)$ & $11(8.7)$ & $19(15.3)$ & $126(4.4)$ & $106(7.7)$ \\
\hline $\begin{array}{l}\text { History of herpes zoster vaccination } \\
{[n(\%)]}\end{array}$ & $1(0.8)$ & 0 & $1(0.8)$ & $102(3.5)$ & $80(5.8)$ \\
\hline History of VTE $[n(\%)]$ & $6(5.0)$ & $4(3.2)$ & $4(3.2)$ & $145(5.0)$ & $70(5.1)$ \\
\hline History of CV events $[n(\%)]$ & $2(1.7)$ & 0 & 0 & $66(2.3)$ & $30(2.2)$ \\
\hline \multicolumn{6}{|l|}{$\mathrm{CV}$ risk factors at baseline $[n(\%)]$} \\
\hline Medical history of hypertension & $44(36.4)$ & $35(27.8)$ & $35(28.2)$ & $1131(39.2)$ & $535(38.9)$ \\
\hline Diabetes & $11(9.1)$ & $16(12.7)$ & $6(4.8)$ & $387(13.4)$ & $188(13.7)$ \\
\hline Current or former tobacco/nicotine use & $63(52.1)$ & $69(54.8)$ & $57(46.0)$ & $1110(38.5)$ & $584(42.5)$ \\
\hline Elevated LDL-C & $19(15.7)$ & $23(18.3)$ & $30(24.2)$ & $801(27.8)$ & $382(27.9)$ \\
\hline Lowered HDL-C & $45(37.2)$ & $40(31.7)$ & $46(37.1)$ & $1641(56.9)$ & $791(57.5)$ \\
\hline Statin use & $11(9.1)$ & $10(7.9)$ & $4(3.2)$ & $339(11.8)$ & $184(13.4)$ \\
\hline
\end{tabular}

$B M I$ body mass index, $c S D M A R D$ conventional synthetic disease-modifying antirheumatic drug, $C V$ cardiovascular, DAS28-CRP disease activity score with 28 joints based on C-reactive protein, $G C$ glucocorticoid, $H D L-C$ high-density lipoprotein cholesterol, $L D L-C$ low-density lipoprotein cholesterol, MTX methotrexate, $R A$ rheumatoid arthritis, $S D$ standard deviation, VTE venous thromboembolism

${ }^{\mathrm{a}} n=2878$

${ }^{\mathrm{b}} n=1368$

${ }^{c} n=2872$

${ }^{\mathrm{d}} n=1373$

${ }^{\mathrm{e}} n=2867$

${ }^{\mathrm{f}} n=51, n=51, n=58, n=1931, n=523$

${ }^{\mathrm{g}}$ Including both oral and non-oral GCs

${ }^{\mathrm{h}} n=57, n=67, n=55, n=1567, n=649$. The prednisone equivalent dose is shown

events in the 7.5 and $15 \mathrm{mg}$ groups were comparable. In comparison with the global population, incidence rates for
AEs and serious AEs were higher in the Japanese population at equivalent upadacitinib doses across the two populations. 
Mortality rates were low across all groups. There were two deaths in the Japanese population, both of which occurred with upadacitinib $30 \mathrm{mg}$ treatment. This included a 78-year-old woman with a history of hypertension and hyperlipidemia who died suddenly after 36 days of treatment, and a 64-year-old woman with no known risk factors who died of pneumothorax respiratory failure after 384 days of treatment.

\subsection{Adverse Events of Special Interest}

Infections were the most common AESI in both Japanese and global populations. EAIRs for infection, serious infection, and opportunistic infection were higher in the Japanese population compared with the global population, and higher with upadacitinib $30 \mathrm{mg}$ versus $15 \mathrm{mg}$ and $7.5 \mathrm{mg}$ (Table 4). In univariable analyses, age $\geq 65$ years, concomitant use of non-methotrexate csDMARDs, and smoking (also significant according to multivariable analyses) were risk factors for serious infection in the global population (Electronic Supplementary Tables 1 and 2). No significant risk factors for serious infection were found in the Japanese population due to the small sample size. Common serious infections in the Japanese population included herpes zoster, pneumonia and, in the $30 \mathrm{mg}$ group only, Pneumocystis jirovecii pneumonia. EAIRs of active tuberculosis were low in the Japanese population and comparable with the global population.

EAIRs for herpes zoster in the Japanese population were 7.8, 12.4, and 16.7 per $100 \mathrm{PY}$ in the $7.5,15$, and $30 \mathrm{mg}$ groups, respectively, compared with 3.7 and 7.0 per $100 \mathrm{PY}$ in the global $6 \mathrm{mg}$ twice daily/15 mg once daily and $12 \mathrm{mg}$ twice daily/30 mg once daily groups. Most cases of herpes zoster in the Japanese population involved a single dermatome; unilateral herpes zoster involving multiple dermatomes was reported in one patient in the $7.5 \mathrm{mg}$ group, three patients in the $15 \mathrm{mg}$ group, and eight patients in the 30 $\mathrm{mg}$ group. Disseminated herpes zoster was reported in four patients in the $15 \mathrm{mg}$ group and four patients in the $30 \mathrm{mg}$ group. Ophthalmic herpes zoster was reported in one patient in the $7.5 \mathrm{mg}$ group and one patient in the $30 \mathrm{mg}$ group. Two patients in the $7.5 \mathrm{mg}$ group, one patient in the $15 \mathrm{mg}$ group, and five patients in the $30 \mathrm{mg}$ group discontinued treatment due to herpes zoster.

History of herpes zoster was a significant risk factor for herpes zoster, based on univariable (Table 5) and multivariable (Electronic Supplementary Table 3) Cox analyses, in both the Japanese and global populations. Other significant risk factors in the univariable analysis included age $\geq 65$ years in the Japanese population, and body weight $<60$ $\mathrm{kg}$ (vs. 60 to $<100$ or $\geq 100 \mathrm{~kg}$ ), BMI $<18.5$ or 18.5 to $<25 \mathrm{~kg} / \mathrm{m}^{2}$ (vs. $\geq 30 \mathrm{~kg} / \mathrm{m}^{2}$ ), and methotrexate + other csDMARDs or csDMARDs other than methotrexate (vs. methotrexate alone) in the global population. EAIRs of

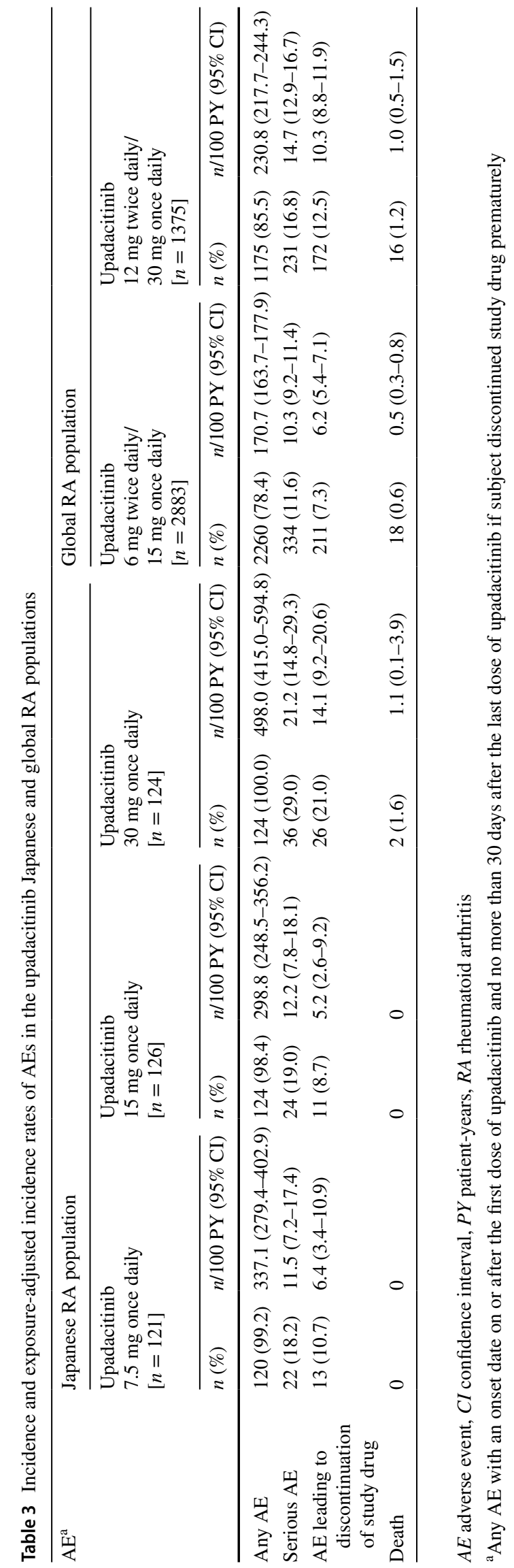




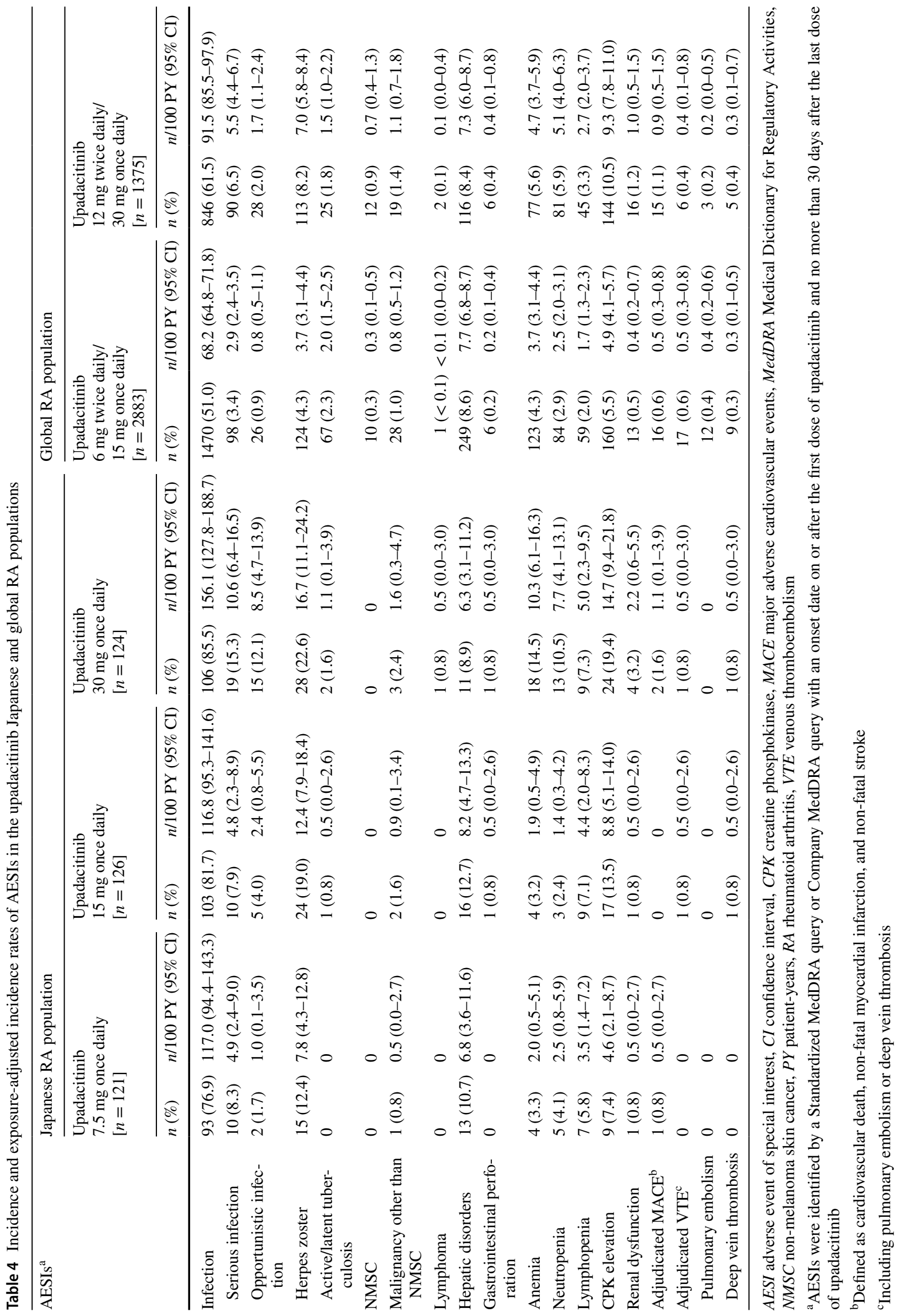


malignancy, MACE, VTE, and hepatic disorder were similar between the Japanese and global populations. Of the VTEs in the Japanese population, one patient in the upadacitinib $30 \mathrm{mg}$ group and one patient in the upadacitinib $15 \mathrm{mg}$ group each had a deep vein thrombosis. The patient in the $30 \mathrm{mg}$ group was a current smoker and the patient in the $15 \mathrm{mg}$ group experienced a VTE following a total knee arthroplasty. No events of non-melanoma skin cancer were reported in the Japanese population (Table 4).

\subsection{Laboratory Abnormalities}

EAIRs of laboratory-related AESIs were similar in the Japanese and global populations (Table 4), except for higher rates of creatine phosphokinase (CPK) elevation in the Japanese population. In the Japanese population, EAIRs of anemia, neutropenia, and CPK elevation were higher in the upadacitinib $30 \mathrm{mg}$ group compared with the upadacitinib 7.5 and $15 \mathrm{mg}$ groups. Grade 3 or 4 decreases in hemoglobin, neutrophils, and lymphocytes, and Grade 3 or 4 increases in $\mathrm{CPK}$, were similar in the upadacitinib 7.5 and $15 \mathrm{mg}$ groups, but higher in the upadacitinib $30 \mathrm{mg}$ group (Table 6).

Overall, mean hemoglobin levels from baseline through 84 weeks were lower in the Japanese population compared with the global population. Despite lower baseline mean hemoglobin levels in the Japanese population, Grade 3 or 4 decreases in hemoglobin were less common with the 7.5 and $15 \mathrm{mg}$ groups in the Japanese population compared with the $15 \mathrm{mg}$ group in the global population. There were slight increases in mean hemoglobin levels with upadacitinib 7.5 and $15 \mathrm{mg}$ (with numerically greater increases with $7.5 \mathrm{mg}$ ) in the Japanese population, which were maintained over time (Electronic Supplementary Fig. 1). Upadacitinib $30 \mathrm{mg}$ was associated with decreases in mean hemoglobin levels in the Japanese and global populations, which were within the normal range of hemoglobin levels in females.

Grade 3 or 4 increases in hepatic enzymes were similar in the upadacitinib 15 and $30 \mathrm{mg}$ groups, but numerically less frequent in the upadacitinib $7.5 \mathrm{mg}$ group.

\section{Discussion}

Among patients enrolled in the upadacitinib clinical RA program, the overall safety profile of upadacitinib was generally similar in the Japanese population compared with the global population. However, incidence rates for serious AEs, infections (including serious infections, opportunistic infections, and herpes zoster), and CPK elevations, were higher in the Japanese population than in the global population at equivalent upadacitinib doses. Consistent with the global population, infections were the most common AESI observed in the Japanese population with upadacitinib. Malignancies,
MACE, and VTE were uncommon with upadacitinib in the Japanese population, and both patients who experienced VTE while receiving upadacitinib had risk factors for VTE.

In Japan, upadacitinib $7.5 \mathrm{mg}$ and $15 \mathrm{mg}$ are both approved for the treatment of RA in patients with inadequate response to existing treatments. The $15 \mathrm{mg}$ dose was associated with greater efficacy compared with the $7.5 \mathrm{mg}$ dose, particularly for more stringent endpoints such as $70 \%$ improvement in American College of Rheumatology criteria and Clinical Disease Activity Index remission at 84 weeks, in the SELECT-SUNRISE study [16]. The results of this integrated safety analysis suggested that the safety profiles of the 7.5 and $15 \mathrm{mg}$ doses were generally similar, with both doses associated with numerically lower EAIRs of AEs, serious AEs, AEs leading to discontinuation, and most AESIs compared with the $30 \mathrm{mg}$ dose, which is currently not approved in Japan or in other countries. However, a degree of dose dependency was observed for opportunistic infections, herpes zoster, and CPK elevations for both the Japanese and global RA populations, but no statistical comparisons were conducted. Despite this, the consequences of a dose reduction from upadacitinib $15 \mathrm{mg}$ once daily to 7.5 $\mathrm{mg}$ once daily for safety reasons are not clear.

Infections, including serious infections and opportunistic infections, were more common in the Japanese population than in the global population. No risk factors for serious infections were found in the Japanese population due to the small sample size. However, age $\geq 65$ years, use of csDMARDs other than methotrexate, and current tobacco/nicotine use were identified as risk factors for serious infections in the global population. A previous report has also shown that smoking is associated with a higher risk of pulmonary infections in patients from Japan receiving immunosuppressant therapies [21]. A numerically greater proportion of patients in the Japanese population were aged $\geq 65$ years ( $29 \%$ vs. $21 \%$ ), had lower body weight (< $60 \mathrm{~kg}: 63 \%$ vs. $18 \%)$, had lower BMI $\left(<25 \mathrm{~kg} / \mathrm{m}^{2}: 78 \%\right.$ vs. $\left.31 \%\right)$, or had current or former tobacco or nicotine use $(51 \%$ vs. $40 \%)$, compared with the global population. These factors may have contributed to the higher incidence of serious infections observed in the Japanese population in this analysis, although further research is required to confirm this.

The higher frequency of herpes zoster in patients in the Japanese population compared with the global clinical trial population is in agreement with previous studies that have shown higher incidence rates of herpes zoster in patients enrolled from Japan and Korea who were treated with baricitinib and tofacitinib compared with other geographic regions [11-15]. The reasons why herpes zoster occurs to a greater extent in populations in Asia than in other regional populations is currently unknown, although it has been suggested that genetic predisposition, regional differences in reporting, and other cultural or medical factors could be involved [13, 
Table 5 Risk factors for herpes zoster in the upadacitinib Japanese and global RA populations based on univariable Cox analysis

\begin{tabular}{|c|c|c|c|c|}
\hline & \multicolumn{2}{|c|}{ Japanese RA population } & \multicolumn{2}{|c|}{ Global RA population } \\
\hline & $N$ & Hazard ratio $(95 \% \mathrm{CI})$ & $N$ & Hazard ratio $(95 \% \mathrm{CI})$ \\
\hline \multicolumn{5}{|l|}{ Age, years } \\
\hline$\geq 65$ & 108 & $1.95(1.03-3.70)$ & 898 & $1.78(1.23-2.57)$ \\
\hline 50 to $<65$ & 164 & $1.12(0.60-2.11)$ & 2050 & $1.51(1.10-2.08)$ \\
\hline$<50$ & 99 & Ref & 1310 & Ref \\
\hline \multicolumn{5}{|l|}{ Sex } \\
\hline Male & 99 & $0.83(0.47-1.46)$ & 872 & $1.11(0.82-1.51)$ \\
\hline Female & 272 & Ref & 3386 & Ref \\
\hline \multicolumn{5}{|l|}{ Weight, kg } \\
\hline$\geq 100$ & 1 & 0 & 543 & $0.50(0.30-0.82)$ \\
\hline 60 to $<100$ & 135 & $0.93(0.57-1.54)$ & 2929 & $0.67(0.50-0.89)$ \\
\hline$<60$ & 235 & Ref & 786 & Ref \\
\hline \multicolumn{5}{|l|}{ BMI, $\mathrm{kg} / \mathrm{m}^{2}$} \\
\hline$<18.5$ & 30 & $0.79(0.26-2.34)$ & 85 & $2.94(1.50-5.74)$ \\
\hline 18.5 to $<25$ & 260 & $0.57(0.24-1.33)$ & 1234 & $1.95(1.41-2.68)$ \\
\hline 25 to $<30$ & 60 & $0.53(0.19-1.47)$ & 1348 & $1.30(0.92-1.83)$ \\
\hline$\geq 30$ & 21 & Ref & 1579 & Ref \\
\hline \multicolumn{5}{|c|}{ EGFR at screening, $\mathrm{mL} / \mathrm{min} / 1.73 \mathrm{~m}^{2}$} \\
\hline 30 to $<60$ & 3 & 0 & 202 & $0.97(0.51-1.84)$ \\
\hline 60 to $<90$ & 83 & $1.05(0.59-1.86)$ & 1747 & $1.02(0.78-1.33)$ \\
\hline$>90$ & 285 & Ref & 2307 & Ref \\
\hline \multicolumn{5}{|l|}{ History of herpes zoster } \\
\hline Yes & 51 & $6.28(3.87-10.19)$ & 232 & $18.20(14.06-23.55)$ \\
\hline No & 320 & Ref & 3998 & Ref \\
\hline \multicolumn{5}{|c|}{ History of herpes zoster vaccination } \\
\hline Yes & 2 & $12.27(1.63-92.18)$ & 182 & $1.08(0.59-1.98)$ \\
\hline No & 341 & Ref & 3772 & Ref \\
\hline \multicolumn{5}{|c|}{ Concomitant csDMARDs at baseline } \\
\hline None & 176 & $1.04(0.59-1.84)$ & 1573 & $1.02(0.77-1.36)$ \\
\hline MTX + other csDMARDs & 44 & $1.04(0.48-2.24)$ & 211 & $1.72(1.08-2.75)$ \\
\hline csDMARDs other than MTX & 33 & $1.03(0.44-2.40)$ & 229 & $1.64(1.03-2.62)$ \\
\hline MTX alone & 116 & Ref & 2244 & Ref \\
\hline \multicolumn{5}{|l|}{ Concomitant GCs at baseline } \\
\hline Yes & 186 & $0.65(0.40-1.05)$ & 2231 & $0.86(0.67-1.11)$ \\
\hline No & 185 & Ref & 2027 & Ref \\
\hline \multicolumn{5}{|l|}{ Diabetes mellitus at baseline } \\
\hline Yes & 33 & $1.16(0.53-2.54)$ & 575 & $0.99(0.66-1.48)$ \\
\hline No & 338 & Ref & 3655 & Ref \\
\hline \multicolumn{5}{|l|}{ History of tobacco/nicotine use } \\
\hline Current user & 76 & $0.55(0.26-1.14)$ & 828 & $1.19(0.85-1.66)$ \\
\hline Former user & 113 & $0.85(0.50-1.46)$ & 866 & $1.49(1.10-2.02)$ \\
\hline Never & 181 & Ref & 2559 & Ref \\
\hline
\end{tabular}

Statistically significant interactions of treatment by risk factors are denoted in bold

$B M I$ body mass index, $C I$ confidence interval, $c S D M A R D$ conventional synthetic disease-modifying antirheumatic drug, EGFR estimated glomerular filtration rate, $G C$ glucocorticoid, MTX methotrexate, $R A$ rheumatoid arthritis, Ref Reference
15]. In this analysis, upadacitinib $15 \mathrm{mg}$ appeared to be associated with a numerically higher incidence of herpes zoster in the Japanese population compared with that of other JAK inhibitors reported in the literature [13-15, 22]. However, any cross-study comparisons should be interpreted with caution due to differences in study design (including potential 
Table 6 Grade 3 or 4 laboratory abnormalities in the upadacitinib Japanese and global RA populations

\begin{tabular}{|c|c|c|c|c|c|}
\hline \multirow[t]{2}{*}{ Laboratory parameters } & \multicolumn{3}{|c|}{ Japanese RA population } & \multicolumn{2}{|c|}{ Global RA population } \\
\hline & $\begin{array}{l}\text { Upadacitinib } \\
7.5 \mathrm{mg} \text { once } \\
\text { daily } \\
{[n=121]}\end{array}$ & $\begin{array}{l}\text { Upadacitinib } \\
15 \mathrm{mg} \text { once daily } \\
{[n=126]}\end{array}$ & $\begin{array}{l}\text { Upadacitinib } \\
30 \mathrm{mg} \text { once daily } \\
{[n=124]}\end{array}$ & $\begin{array}{l}\text { Upadacitinib } \\
6 \mathrm{mg} \text { twice } \\
\text { daily/ } \\
15 \mathrm{mg} \text { once } \\
\text { daily } \\
{[n=2883]}\end{array}$ & $\begin{array}{l}\text { Upadacitinib } \\
12 \text { mg twice daily/ } \\
30 \text { mg once daily } \\
{[n=1375]}\end{array}$ \\
\hline \multicolumn{6}{|l|}{ Hemoglobin (g/L) } \\
\hline $\begin{array}{l}\text { Grade } 3(70 \text { to }<80 \text { or } \\
\text { decreased } 21 \text { to }<30 \text { ) }\end{array}$ & $2(1.7)$ & $2(1.6)$ & $16(12.9)$ & $169(5.9)^{\mathrm{a}}$ & $160(11.7)^{\mathrm{b}}$ \\
\hline $\begin{array}{l}\text { Grade } 4(<70 \text { or } \\
\text { decreased } \geq 30)\end{array}$ & $1(0.8)$ & 0 & $9(7.3)$ & $51(1.8)^{\mathrm{a}}$ & $59(4.3)^{\mathrm{b}}$ \\
\hline \multicolumn{6}{|l|}{ Neutrophils $\left(\times 10^{9} / \mathrm{L}\right)$} \\
\hline Grade $3(0.5$ to $<1.0)$ & $2(1.7)$ & $1(0.8)$ & $4(3.2)$ & $29(1.0)^{\mathrm{c}}$ & $34(2.5)^{\mathrm{d}}$ \\
\hline Grade $4(<0.5)$ & $1(0.8)$ & 0 & 0 & $7(0.2)^{\mathrm{c}}$ & $3(0.2)^{\mathrm{d}}$ \\
\hline \multicolumn{6}{|l|}{ Lymphocytes $\left(\times 10^{9} / \mathrm{L}\right)$} \\
\hline Grade $3(0.5$ to $<1.0)$ & $48(39.7)$ & $40(31.7)$ & $56(45.2)$ & $572(20.0)^{\mathrm{c}}$ & $333(24.4)^{\mathrm{d}}$ \\
\hline Grade $4(<0.5)$ & $6(5.0)$ & $2(1.6)$ & $6(4.8)$ & $45(1.6)^{\mathrm{c}}$ & $39(2.9)^{\mathrm{d}}$ \\
\hline \multicolumn{6}{|l|}{ CPK (U/L) } \\
\hline $\begin{array}{c}\text { Grade } 3(>5.0 \text { to } \\
10.0 \times \mathrm{ULN})\end{array}$ & $3(2.5)$ & $3(2.4)$ & $5(4.0)$ & $48(1.7)^{\mathrm{e}}$ & $29(2.1)^{\mathrm{f}}$ \\
\hline $\begin{array}{l}\text { Grade } 4 \\
\quad(>10.0 \times \mathrm{ULN})\end{array}$ & $1(0.8)$ & $1(0.8)$ & $4(3.2)$ & $15(0.5)^{\mathrm{e}}$ & $16(1.2)^{\mathrm{f}}$ \\
\hline \multicolumn{6}{|l|}{ Creatinine $(\mu \mathrm{mol} / \mathrm{L})$} \\
\hline $\begin{array}{l}\text { Grade } 3(>3.0 \text { to } \\
6.0 \times \mathrm{ULN})\end{array}$ & 0 & 0 & 0 & $1(<0.1)^{\mathrm{c}}$ & $1(<0.1)^{\mathrm{g}}$ \\
\hline Grade $4(>6.0 \times$ ULN $)$ & 0 & $1(0.8)$ & 0 & $2(<0.1)^{\mathrm{c}}$ & $0^{\mathrm{g}}$ \\
\hline \multicolumn{6}{|l|}{$\begin{array}{l}\text { Alanine aminotransferase } \\
\text { (U/L) }\end{array}$} \\
\hline $\begin{array}{l}\text { Grade } 3(>3.0 \text { to } \\
8.0 \times \text { ULN })\end{array}$ & $1(0.8)$ & $3(2.4)$ & $5(4.0)$ & $89(3.1)^{\mathrm{h}}$ & $48(3.5)^{\mathrm{i}}$ \\
\hline Grade $4(>8.0 \times$ ULN $)$ & 0 & $1(0.8)$ & $1(0.8)$ & $12(0.4)^{\mathrm{h}}$ & $7(0.5)^{\mathrm{i}}$ \\
\hline \multicolumn{6}{|l|}{$\begin{array}{l}\text { Aspartate aminotrans- } \\
\text { ferase }(\mathrm{U} / \mathrm{L})\end{array}$} \\
\hline $\begin{array}{l}\text { Grade } 3(>3.0 \text { to } \\
8.0 \times \text { ULN })\end{array}$ & $1(0.8)$ & $2(1.6)$ & $2(1.6)$ & $55(1.9)^{\mathrm{e}}$ & $22(1.6)^{\mathrm{i}}$ \\
\hline Grade $4(>8.0 \times$ ULN $)$ & 0 & $1(0.8)$ & 0 & $8(0.3)^{\mathrm{e}}$ & $5(0.4)^{i}$ \\
\hline
\end{tabular}

Data are expressed as $n(\%)$

$C P K$ creatine phosphokinase, $R A$ rheumatoid arthritis, $U L N$ upper limit of normal

${ }^{\mathrm{a}} n=2858$

$\mathrm{b}_{n}=1364$

${ }^{\mathrm{c}} n=2857$

${ }^{\mathrm{d}} n=1363$

${ }^{\mathrm{e}} n=2855$

${ }^{\mathrm{f}} n=1367$

$\mathrm{g}_{n}=1368$

${ }^{\mathrm{h}} n=2856$

${ }^{\mathrm{i}} n=1366$

differences in the calculation of herpes zoster rates), patient populations, and baseline characteristics, especially those associated with significantly greater risk of herpes zoster such as age and history of herpes zoster. 
History of herpes zoster was numerically more common in the Japanese population and was an independent risk factor for herpes zoster while receiving upadacitinib. Herpes zoster vaccination did not appear to reduce the risk of herpes zoster in the global population. However, as we do not have detailed information regarding the types and dates of the vaccination, it is difficult to assess the benefits of vaccination in this patient population. Furthermore, the benefits of herpes zoster vaccination in the Japanese population could not be assessed as only two patients were vaccinated. More information about the impact of herpes zoster vaccination on the risk of herpes zoster among patients receiving upadacitinib or other JAK inhibitors is necessary to inform future clinical practice. The increased risk of herpes zoster associated with JAK inhibitors, including upadacitinib, should be considered and explained to the patient before prescription, particularly to those who have a history of herpes zoster.

In addition to geographic region, the risk of AESIs may also vary with race or ethnicity. For example, in the general population, Asian Americans had a higher risk of herpes zoster [23] and a lower risk of VTE [24] compared with non-Asian Americans. In the current analysis, all patients in the Japanese population were Asian by race, and most were from a Japanese ethnic background. It was however not an objective to investigate the effect of race or ethnicity on the safety profile of upadacitinib in patients with RA. Thus, the current results should be interpreted as the safety profile of patients enrolled in clinical trials from Japan.

The current analysis has several limitations. As an analysis of long-term follow-up data, this analysis was conducted without a placebo comparison. However, data from placebocontrolled periods of the studies included in this analysis have indicated a favorable benefit-risk balance for upadacitinib $15 \mathrm{mg}$ once daily compared with placebo [25]. Overall conclusions from placebo-controlled data were generally consistent with the current analysis. Moreover, comparisons across the three upadacitinib doses and between the Japanese and global populations should be interpreted with caution as no statistical comparisons were performed. Another limitation is the small sample size of the Japanese population evaluated in this study, especially when compared with the global population. The median exposure to upadacitinib in this analysis was up to 600 days, which may not be long enough to accurately assess the incidence of rare events. Furthermore, patients from Japan were enrolled in a limited set of clinical trials (three of eight clinical trials in the upadacitinib phase II/III program).

\section{Conclusions}

Upadacitinib at equivalent doses generally had a similar safety profile in the Japanese and global populations enrolled in the RA clinical program, with the exception of higher rates of serious infections, opportunistic infections, herpes zoster, and CPK elevations in the Japanese population. In the majority of patients enrolled in Japan from the three clinical trials included in the current analysis, the safety profiles of upadacitinib $15 \mathrm{mg}$ and $7.5 \mathrm{mg}$ were generally similar, except for numerically lower EAIRs of opportunistic infections, herpes zoster, and CPK elevations with the $7.5 \mathrm{mg}$ dose compared with the $15 \mathrm{mg}$ dose, although no statistical comparisons were conducted. It is important that rheumatologists consider the risk of herpes zoster in their benefit-risk assessment prior to prescribing JAK inhibitors. Further postmarketing research will continue to clarify the safety of upadacitinib in patients with RA in Japan, especially regarding the risk of infections, in real-world settings.

Supplementary Information The online version contains supplementary material available at https://doi.org/10.1007/s40264-021-01067-x.

Acknowledgements AbbVie funded this study and participated in the study design, research, analysis, data collection, interpretation of data, and review and approval of the publication. All authors had access to relevant data and participated in the drafting, review, and approval of this publication. No honoraria or payments were made for authorship. Medical writing support was provided by Hilary Wong, PhD, and John Ewbank, PhD, of 2 the Nth (Cheshire, UK) and was funded by AbbVie.

\section{Declarations}

Funding This work was supported by AbbVie, who contributed to the study design; data collection, analysis and interpretation; and writing, reviewing, and approval of the final version.

Conflicts of Interest Kunihiro Yamaoka has received speakers bureau fees from AbbVie GK, Astellas Pharma Inc., Bristol-Myers Squibb, Chugai Pharmaceutical Co. Ltd, Mitsubishi Tanabe Pharma Corporation, Pfizer Japan Inc., and Takeda Pharmaceutical Co. Ltd. Yoshiya Tanaka has received speaking fees and/or honoraria from AbbVie, Asahi-Kasei Pharma Corporation, Astellas Pharma Inc., BristolMyers Squibb, Chugai Pharmaceutical Co. Ltd, Daiichi Sankyo Co. Ltd, Eisai Co. Ltd, Eli Lilly Japan KK, Gilead, GlaxoSmithKline KK, Janssen Pharmaceutical KK, Mitsubishi Tanabe Pharma Corporation, Novartis, Pfizer Japan Inc., Sanofi KK, and YL Biologics; and research grants from AbbVie, Chugai Pharmaceutical Co. Ltd, Daiichi Sankyo Co. Ltd, Eisai Co. Ltd, Mitsubishi Tanabe Pharma Corporation, Takeda Pharmaceutical Co. Ltd, and UCB. Hideto Kameda has received consulting fees, speaking fees, and/or honoraria from $\mathrm{AbbVie}$ GK, Asahi-Kasei Pharma Corporation, Bristol-Myers Squibb, Chugai 
Pharmaceutical Co. Ltd, Eli Lilly Japan KK, Gilead, Janssen Pharmaceutical KK, Mitsubishi Tanabe Pharma Corporation, Novartis, Pfizer Japan Inc., Sanofi KK, and UCB Japan; and research grants from AbbVie GK, Asahi-Kasei Pharma Corporation, Astellas Pharma Inc., Chugai Pharmaceutical Co. Ltd, Eisai Co. Ltd, Mitsubishi Tanabe Pharma Corporation, and Novartis. Nasser Khan, Nobuhito Sasaki, Yanna Song, and Ying Zhang are employees of AbbVie and may own stocks or stock options. Masayoshi Harigai has received grants from AbbVie Japan Co. Ltd, Bristol-Myers Squibb KK, Chugai Pharmaceutical Co. Ltd, Eisai Co. Ltd, Mitsubishi Tanabe Pharma Co., Santen Pharmaceutical Co. Ltd, Takeda Pharmaceutical Co. Ltd, and Teijin Pharma, Ltd; and personal fees from AbbVie Japan Co. Ltd, Astellas Pharma Inc., Bristol-Myers Squibb KK, Chugai Pharmaceutical Co. Ltd, Eisai Co. Ltd, Janssen Pharmaceutical KK, Mitsubishi Tanabe Pharma Co., Pfizer Japan Inc., Santen Pharmaceutical Co. Ltd, Takeda Pharmaceutical Co. Ltd, and Teijin Pharma, Ltd. Tsutomu Takeuchi has received grants from AbbVie GK, Asahi-Kasei Pharma Corporation, Astellas Pharma Inc., AYUMI Pharmaceutical Corporation, Chugai Pharmaceutical Co. Ltd, Daiichi Sankyo Co. Ltd, Eisai Co. Ltd, Mitsubishi Tanabe Pharma Corporation, Nippon Kayaku Co. Ltd, Novartis Pharma KK, Pfizer Japan Inc., and Takeda Pharmaceutical Co. Ltd; and personal fees from AbbVie GK, Astellas Pharma Inc., AstraZeneca KK, Bristol-Myers Squibb KK, Chugai Pharmaceutical Co. Ltd, Daiichi Sankyo Co. Ltd, Eisai Co. Ltd, Eli Lilly Japan KK, GlaxoSmithKline KK, Janssen Pharmaceutical KK, Mitsubishi Tanabe Pharma Corporation, Nippon Kayaku Co. Ltd, Novartis Pharma KK, Pfizer Japan Inc., Sanofi KK, Teijin Pharma Ltd, Taiho Pharmaceutical Co. Ltd, Taisho Pharmaceutical Co. Ltd, Takeda Pharmaceutical Co. Ltd, and UCB.

Ethics Approval All studies were conducted according to the International Conference on Harmonization of Technical Requirements for Pharmaceuticals for Human Use guidelines, applicable regulations and guidelines governing clinical study conduct, and the Declaration of Helsinki. Study-related documents were reviewed and approved by independent Ethics Committees and Institutional Review Boards.

Consent to Participate All patients provided written informed consent.

Consent for Publication Not applicable.

Availability of Data and Material These clinical trial data can be requested by any qualified researchers who engage in rigorous, independent scientific research, and will be provided following review and approval of a research proposal and Statistical Analysis Plan and execution of a Data Sharing Agreement. Data requests can be submitted at any time and the data will be accessible for 12 months, with possible extensions considered. For more information on the process, or to submit a request, visit the following link: https://www.abbvie.com/ our-science/clinical-trials/clinical-trials-data-and-information-sharing/ data-and-information-sharing-with-qualified-researchers.html.

Code Availability Not applicable.

Author Contributions All authors contributed to the study concept/ design, data acquisition, analysis, and interpretation, as well as writing and critical review of the manuscript. All authors provided final approval of the submitted version.

Open Access This article is licensed under a Creative Commons Attribution-NonCommercial 4.0 International License, which permits any non-commercial use, sharing, adaptation, distribution and reproduction in any medium or format, as long as you give appropriate credit to the original author(s) and the source, provide a link to the Creative Commons licence, and indicate if changes were made. The images or other third party material in this article are included in the article's Creative Commons licence, unless indicated otherwise in a credit line to the material. If material is not included in the article's Creative Commons licence and your intended use is not permitted by statutory regulation or exceeds the permitted use, you will need to obtain permission directly from the copyright holder. To view a copy of this licence, visit http://creativecommons.org/licenses/by-nc/4.0/.

\section{References}

1. Alunno A, Padjen I, Fanouriakis A, Boumpas DT. Pathogenic and therapeutic relevance of JAK/STAT signaling in systemic lupus erythematosus: integration of distinct inflammatory pathways and the prospect of their inhibition with an oral agent. Cells. 2019;8(8):898. https://doi.org/10.3390/cells8080898.

2. Malemud CJ. The role of the JAK/STAT signal pathway in rheumatoid arthritis. Ther Adv Musculoskelet Dis. 2018;10(5-6):11727. https://doi.org/10.1177/1759720X18776224.

3. McInnes IB, Schett G. Pathogenetic insights from the treatment of rheumatoid arthritis. Lancet. 2017;389(10086):2328-37. https:// doi.org/10.1016/S0140-6736(17)31472-1.

4. Parmentier JM, Voss J, Graff C, Schwartz A, Argiriadi M, Friedman $\mathrm{M}$, et al. In vitro and in vivo characterization of the JAK1 selectivity of upadacitinib (ABT-494). BMC Rheumatol. 2018;2:23. https://doi.org/10.1186/s41927-018-0031-x.

5. Burmester GR, Kremer JM, Van den Bosch F, Kivitz A, Bessette L, Li Y, et al. Safety and efficacy of upadacitinib in patients with rheumatoid arthritis and inadequate response to conventional synthetic disease-modifying anti-rheumatic drugs (SELECTNEXT): a randomised, double-blind, placebo-controlled phase 3 trial. Lancet. 2018;391(10139):2503-12. https://doi.org/10.1016/ S0140-6736(18)31115-2.

6. Fleischmann R, Pangan AL, Song IH, Mysler E, Bessette L, Peterfy $\mathrm{C}$, et al. Upadacitinib versus placebo or adalimumab in patients with rheumatoid arthritis and an inadequate response to methotrexate: results of a phase III, double-blind, randomized controlled trial. Arthritis Rheum. 2019;71(11):1788-800. https:// doi.org/10.1002/art.41032.

7. Genovese MC, Fleischmann R, Combe B, Hall S, RubbertRoth A, Zhang Y, et al. Safety and efficacy of upadacitinib in patients with active rheumatoid arthritis refractory to biologic disease-modifying anti-rheumatic drugs (SELECT-BEYOND): a double-blind, randomised controlled phase 3 trial. Lancet. 2018;391(10139):2513-24. https://doi.org/10.1016/S01406736(18)31116-4.

8. Smolen JS, Pangan AL, Emery P, Rigby W, Tanaka Y, Vargas JI, et al. Upadacitinib as monotherapy in patients with active rheumatoid arthritis and inadequate response to methotrexate (SELECTMONOTHERAPY): a randomised, placebo-controlled, doubleblind phase 3 study. Lancet. 2019;393:2303-11. https://doi.org/ 10.1016/S0140-6736(19)30419-2.

9. van Vollenhoven R, Takeuchi T, Pangan AL, Friedman A, Mohamed MF, Chen S, et al. Efficacy and safety of upadacitinib monotherapy in methotrexate-naïve patients with moderately to severely active rheumatoid arthritis (SELECT-EARLY): a randomized, double-blind, active-comparator, multi-center, multicountry trial. Arthritis Rheum. 2020;72:1607-20. https://doi.org/ 10.1002/art.41384.

10. Tanaka Y. A review of upadacitinib in rheumatoid arthritis. Mod Rheumatol. 2020;30(5):779-87. https://doi.org/10.1080/14397 595.2020.1782049.

11. Mimori T, Harigai M, Atsumi T, Kuwana M, Takei S, Tamura $\mathrm{N}$, et al. AB0495 post-marketing surveillance of tofacitinib in 
Japanese patients with rheumatoid arthritis: an interim report of safety data. Ann Rheum Dis. 2018;77(S2):1408.

12. Tanaka Y, Takeuchi T, Tanaka S, Kawakami A, Iwasaki M, Song YW, et al. Efficacy and safety of peficitinib (ASP015K) in patients with rheumatoid arthritis and an inadequate response to conventional DMARDs: a randomised, double-blind, placebo-controlled phase III trial (RAJ3). Ann Rheum Dis. 2019;78(10):1320-32. https://doi.org/10.1136/annrheumdis-2019-215163.

13. Winthrop KL, Yamanaka H, Valdez H, Mortensen E, Chew R, Krishnaswami S, et al. Herpes zoster and tofacitinib therapy in patients with rheumatoid arthritis. Arthritis Rheumatol. 2014;66:2675-84. https://doi.org/10.1002/art.38745.

14. Harigai M, Takeuchi T, Smolen JS, Winthrop KL, Nishikawa A, Rooney TP, et al. Safety profile of baricitinib in Japanese patients with active rheumatoid arthritis with over 1.6 years median time in treatment: an integrated analysis of Phases 2 and 3 trials. Mod Rheumatol. 2020;30:36-43. https://doi.org/10.1080/14397595. 2019.1583711 .

15. Winthrop KL, Curtis JR, Lindsey S, Tanaka Y, Yamaoka K, Valdez $\mathrm{H}$, et al. Herpes zoster and tofacitinib: clinical outcomes and the risk of concomitant therapy. Arthritis Rheumatol. 2017;69:1960-8. https://doi.org/10.1002/art.40189.

16. Kameda H, Takeuchi T, Yamaoka K, Oribe M, Kawano M, Zhou Y, et al. Efficacy and safety of upadacitinib in Japanese patients with rheumatoid arthritis (SELECT-SUNRISE): a placebo-controlled phase IIb/III study. Rheumatology (Oxford). 2020;59(11):3303-13. https://doi.org/10.1093/rheumatology/ keaa084.

17. Kremer JM, Emery P, Camp HS, Friedman A, Wang L, Othman AA, et al. A phase IIb study of ABT-494, a selective JAK-1 inhibitor, in patients with rheumatoid arthritis and an inadequate response to anti-tumor necrosis factor therapy. Arthritis Rheumatol. 2016;68:2867-77. https://doi.org/10.1002/art.39801.

18. Genovese MC, Smolen JS, Weinblatt ME, Burmester GR, Meerwein S, Camp HS, et al. Efficacy and safety of ABT-494, a selective JAK-1 inhibitor, in a phase IIb study in patients with rheumatoid arthritis and an inadequate response to methotrexate. Arthritis Rheumatol. 2016;68:2857-66. https://doi.org/10.1002/ art.39808.

19. Mohamed MF, Zeng J, Marroum PJ, Song IH, Othman AA. Pharmacokinetics of upadacitinib with the clinical regimens of the extended-release formulation utilized in rheumatoid arthritis phase 3 trials. Clin Pharmacol Drug Dev. 2019;8:208-16. https:// doi.org/10.1002/cpdd.462.

20. Kameda H, Fujii T, Nakajima A, Koike R, Sagawa A, Kanbe K, et al. Japan College of Rheumatology guideline for the use of methotrexate in patients with rheumatoid arthritis. Mod Rheumatol. 2019;29:31-40. https://doi.org/10.1080/14397595.2018. 1472358.

21. Yamazaki H, Sakai R, Koike R, Miyazaki Y, Tanaka M, Nanki T, et al. Assessment of risks of pulmonary infection during 12 months following immunosuppressive treatment for active connective tissue diseases: a large-scale prospective cohort study. J Rheumatol. 2015;42:614-22. https://doi.org/10.3899/jrheum.140778.

22. Yamanaka H, Tanaka Y, Takeuchi T, Sugiyama N, Yuasa H, Toyoizumi S, et al. Tofacitinib, an oral Janus kinase inhibitor, as monotherapy or with background methotrexate, in Japanese patients with rheumatoid arthritis: an open-label, long-term extension study. Arthritis Res Ther. 2016;18:34. https://doi.org/10.1186/ s13075-016-0932-2.

23. Tseng HF, Chi M, Hung P, Harpaz R, Schmid DS, LaRussa P, et al. Family history of zoster and risk of developing herpes zoster. Int J Infect Dis. 2018;66:99-106. https://doi.org/10.1016/j.ijid. 2017.11.016.

24. Klatsky AL, Armstrong MA, Poggi J. Risk of pulmonary embolism and/or deep venous thrombosis in Asian-Americans. Am J Cardiol. 2000;85:1334-7. https://doi.org/10.1016/s0002-9149(00) 00766-9.

25. Conaghan PG, Mysler E, Tanaka Y, Da Silva-Tillmann B, Shaw $\mathrm{T}$, Liu J, et al. Upadacitinib in rheumatoid arthritis: a benefit-risk assessment across a phase III program. Drug Saf. 2021. https:// doi.org/10.1007/s40264-020-01036-w. 